\title{
KONSTRUKSI NILAI MULTIKULTURALISME PADA MASYARAKAT HAURGEULIS KABUPATEN INDRAMAYU
}

\author{
THE CONSTRUCTION OF MULTICULTURALISM VALUES \\ IN HAURGEULIS SOCIETY, INDRAMAYU REGENCY
}

\author{
Suciyadi Ramdhani \\ IKKON Badan Ekonomi Kreatif (Bekraf) \\ Jln. Merdeka Selatan No.13 - Jakarta Pusat \\ e-mail: suciyadiramdhani@gmail.com
}

\begin{abstract}
Abstrak
Tulisan ini menjelaskan proses pembentukan nilai multikulturalisme pada masyarakat Haurgeulis, Indramayu yang dikaji melalui metode kualitatif. Pengumpulan data menggunakan teknik pengamatan terlibat, wawancara mendalam, dan studi literatur. Hasilnya menunjukkan bahwa kehidupan multikultural di Haurgeulis dibentuk oleh empat kelompok etnik pendatang: Jawa, Sunda, Arab, dan Tionghoa di awal abad ke-20. Setiap kelompok etnik memiliki keahliannya masing-masing, seperti pertanian yang didominasi keturunan Jawa dan Sunda, sebagaimana keturunan Arab dan Tionghoa di bidang perdagangan. Adanya keahlian pekerjaan membentuk hubungan antaretnik menjadi saling ketergantungan dalam kehidupan ekonomi. Dengan saling ketergantungan, masyarakat di Haurgeulis menunjukkan sikap penerimaan dan tidak diskriminatif kepada liyannya. Pengalaman hidup bersama tersebut semakin membentuk nilai-nilai multikulturalisme pada masyarakat Haurgeulis.
\end{abstract}

Kata kunci: etnisitas, multikultural, Haurgeulis.

\begin{abstract}
This paper describes the process of value creation of multiculturalism in Haurgeulis Indramayu society which is studied through qualitative method. The Data is collected through observational techniques, in-depth interviews, and literature studies. The results show that multicultural life in Haurgeulis was formed by four ethnic groups of immigrants: Java, Sunda, Arabian and Chinese in the early 20th century. Each ethnic group has its own expertise, such as agriculture that dominated by Javanese and Sundanese descent, while the Arab and Chinese descendants of trade. The existence of job skills forms inter-ethnic relations into interdependence in economic life. With interdependence, people in Haurgeulis shows acceptance and nondiscriminatory attitude to the others. Life experience in living together increasingly shapes the values of multiculturalism in Haurgeulis society.
\end{abstract}

Keywords: ehnicity, multicultural, Haurgeulis.

\section{A. PENDAHULUAN}

Tulisan ini mengkaji proses pembentukan nilai multikulturalisme pada masyarakat Haurgeulis, yang telah hidup bersama dalam perbedaan sukubangsa dan agama serta disatukan oleh adanya kemajemukan.

Multikulturalisme menekankan pemahaman dan penerimaan terhadap perbedaan hidup dalam konteks sosialbudaya, baik secara individu maupun kelompok (Kymlicka, 2002). Dalam masyarakat multikultural setiap golongan 
etnik yang ada akan selalu dihadapkan pada hubungan dengan liyan, dan perbedaan itu muncul ketika berhadapan dalam interaksi sosial yang dicirikan oleh adanya persamaan, atau perbedaan secara fisik maupun kultural (Lewellen, 2003:166-167).

Kajian ini banyak ditemukan di Indonesia, khususnya di perkotaan atau tempat yang biasanya memiliki nilai ekonomis berkat letaknya atau fungsinya yang mempertemukan berbagai golongan sosial budaya, sebagaimana fokus dalam tulisan ini yaitu pada masyarakat multikultural.

Haurgeulis merupakan kota kecil dengan cerminan masyarakat multietnik, yang penduduknya terdiri atas beragam sukubangsa, di antaranya orang Sunda, Jawa, Minangkabau, Arab dan Tionghoa. Banyak penelitian di beberapa wilayah multietnik lain memaparkan tentang potensi konflik di kota-kota kecil (Klinken, 2007).

Di Kota Kecamatan Haurgeulis walaupun terdiri atas beragam golongan budaya, konflik cenderung jarang terjadi atau hanya dalam skala kecil, meskipun di sekitar wilayah Haurgeulis terdapat beberapa tempat yang berstigma dan memiliki potensi konflik seperti adanya tradisi dan lokalisasi PSK dan pesantren Al-Zaytun yang dianggap kontroversi karena diisukan memiliki visi meneruskan Negara Islam Indonesia (NII) (Hadi, 2013; Humardhani, 2015; Santoso, 2013).

Selain itu, kota Kecamatan Haurgeulis yang secara geografis berada di wilayah pertanian, diimbangi juga oleh perdagangan bersamaan dengan kedatangan penduduk dari berbagai latar belakang sosial budaya, sehingga hubungan di antara penduduknya yang beragam itu menonjol pada aspek perekonomian. Kajian-kajian lain menunjukkan bahwa pertemuan antaretnik dengan kepentingan ekonomi dapat menjadi sumber-sumber konflik, terutama jika terdapat kesenjangan ekonomi antargolongan (Suparlan, 2005; Salim,
2006; Klinken, 2007; Hoon, 2012). Namun banyaknya pendatang (migran) di kota Kecamatan Haurgeulis dalam rangka penghidupan, tidak memunculkan persoalan tersebut. Kota Kecamatan Haurgeulis terkesan damai meskipun terdiri atas beragam sukubangsa, sehingga itu mencerminkan masyarakat multikulturalis, yang cenderung memiliki sikap toleran dalam memandang individu atau kelompok lain yang berbeda latar belakang budayanya.

Samovar dkk.

(2014:200)

menjelaskan hubungan antaretnik yang salah satunya dicirikan oleh adanya sikap toleran akan meningkatkan percampuran budaya dan percampuran ini menghasilkan orang-orang yang memiliki berbagai jenis identitas budaya, sehingga dapat meminimalisasi konflik antargolongan. Sehubungan dengan pemahaman tersebut, maka tulisan ini hendak mendeskripsikan bagaimana proses akulturasi budaya antargolongan sosial yang ada di Haurgeulis.

Penelitian ini memerhatikan beberapa konsep, yaitu (1) masyarakat multikultural; (2) mayoritas-minoritas dan dominan; (3) identitas dalam kerangka etnisitas; (4) struktur dan agen dalam praktik kehidupan multikultural; (5) konflik dan resolusi konflik pada masyarakat multikultural.

Tinjauan pertama mengenai masyarakat multikultural untuk mengetahui pola hubungan antaretnik pada wilayah yang ditempati beragam sukubangsa. Tinjauan kedua tentang konsep mayoritas-minoritas dan dominan digunakan untuk mengetahui situasi budaya pada masyarakat multikultural, karena di wilayah multikultural terdapat dua kemungkinan yaitu memiliki atau tidak memiliki kebudayaan dominan sebagai bagian dari relasi antara mayoritasminoritas. Tinjauan ketiga, konsep identitas dalam kerangka etnisitas dimaksudkan untuk menguraikan identifikasi anggota suatu golongan etnik yang memiliki budaya berbeda dengan 
liyan, dan pola relasi antaretnik yang berpengaruh terhadap pembentukan identitas suatu masyarakat multukultural. Tinjauan keempat membantu peneliti dalam memandang kehidupan multikultural dan individu-individu sebagai aktor yang ada di dalamnya melalui pendekatan konstruksi sosial dari Berger dan Luckmann. Tinjauan kelima, terkait konflik dan resolusi konflik menguraikan bagaimana konflik bisa terjadi di kota-kota kecil, dan setelah identifikasi sumber konflik maka akan ditemukan cara-cara untuk menghindari konflik.

Kajian ini menggunakan teori konstruksi sosial. Dalam pendekatan ini, masyarakat adalah sebagai kenyataan objektif sekaligus kenyataan subjektif. Dengan kata lain, individu adalah pembentuk masyarakat dan masyarakat adalah pembentuk individu. Untuk menghubungkan dialektika tersebut, penelitian ini menggunakan konsep eksternalisasi, objektivasi, dan internalisasi. Eksternalisasi adalah penyesuaian diri dengan dunia sosiokultural sebagai produk manusia, dan objektivasi adalah interaksi sosial dalam dunia intersubjektif yang dilembagakan atau mengalami proses intitusionalisasi. Sedangkan internalisasi adalah pengidentifikasian diri individu di tengah lembaga-lembaga sosial yang selanjutnya menjadi bermakna (Berger dan Luckmann, 2013:177).

Eksternalisasi

memerhatikan

bagaimana individu-individu dari tiap golongan etnik menempatkan diri dalam lingkungan sosial di Haurgeulis, sebagaimana hakikat manusia sebagai makhluk sosial. Eksternalisasi tersebut menghasilkan interaksi sosial yang berulang-ulang dalam kehidupan seharihari, baik di lingkungan keluarga, kerja, sekolah, dan pemukiman. Melalui interaksi, individu belajar tentang liyan yang menjadi pengetahuan baru baginya. Pengetahuan tentang liyan menjadi kesadaran umum yang diketahui masyarakat, kemudian dilembagakan dalam sejumlah bidang kehidupan. Selanjutnya, pengetahuan tersebut melahirkan pandangan-pandangan yang memengaruhi hubungan individu dengan liyan, untuk kemudian digunakan sebagai landasan dalam merumuskan tindakan yang akan dilakukan terhadap liyan. Dalam proses itulah, terjadi internalisasi, yaitu suatu pemahaman dan penafsiran yang langsung dari peristiwa-peristiwa sebagai suatu pengungkapan makna dari individu untuk selanjutnya disosialisasikan kembali. Dengan demikian masyarakat multikultural ini bukan hanya sebagai hasil pengalaman hidup interaksi antargolongan etnik (masyarakat sebagai produk individu), melainkan juga kembali membentuk pola hubungan individu dengan liyannya dalam berinteraksi (individu sebagai produk masyarakat).

Sebagai suatu proses, pengalaman hidup pada masyarakat multikultural ini membentuk dan membentuk-ulang cara orang dalam memandang dan memahami liyan yang berbeda identitas budayanya. Pengalaman hidup ini dikonstruksi oleh individu menjadi sebuah nilai kehidupan multikultural yang diwujudkan melalui pandangan dan tindakan dalam suatu hubungan sosial. Pandangan dan tindakan ini tergantung dari pengalaman individu terkait pengetahuan yang didapat selama berlangsungnya interaksi. Pengalaman tersebut dapat digolongkan menjadi dua kategori, yakni kategori kultural, dan struktural. Kategori kultural dibentuk oleh keyakinan agama, konsep diri dan liyan, masyarakat asli dan pendatang, serta pengetahuan tentang kerjasama dan konflik dalam kehidupan masyarakat. Adapun kategori struktural terdapat dalam mobilitas sosial yang terkait dengan pendidikan, dan pembagian kerja di antara golongan-golongan etnik. Oleh karena itu, penelitian ini juga memfokuskan pada hubungan antarindividu yang mana dalam penelitian sebelumnya hanya berbicara pada ranah antarkelompok. 


\section{B. METODE PENELITIAN}

Kajian ini menekankan pada aspek pemahaman proses dan makna terutama dalam kaitannya dengan kehidupan masyarakat multikultural, sebagaimana Creswell (2013:4) menjelaskan bahwa penelitian kualitatif merupakan metode untuk mengeksplorasi dan memahami makna oleh sejumlah individu atau sekelompok orang. Penerapan metode tersebut diwujudkan melalui pemilihan informan, teknik pengumpulan data, analisis data.

Pemilihan informan dilakukan berdasarkan kerangka purposive random sampling, yaitu dengan memilih subjek yang memiliki pengetahuan dan menguasai informasi yang berkaitan dengan kehidupan multikultural di Haurgeulis. Mengingat keterbatasan peneliti tentang kualitas informan di Haurgeulis, maka diputuskan penelitian ini menggunakan informan kunci. Melalui informan kunci ini peneliti mendapatkan sejumlah informan yang berasal dari sukubangsa yang berbeda dengan beragam profesi dan latar belakang budaya seperti pengusaha, petani, pedagang pasar, PNS, veteran TNI, guru, mahasiswa, pelajar SMA/SMK, dan pengrajin.

Data yang dikumpulkan dalam penelitian ini berupa riwayat masyarakat Haurgeulis, berbagai aktivitas yang melibatkan warga dari beragam sukubangsa, pandangan individu terhadap liyan, bidang-bidang kehidupan yang menjadi batas-batas kelompok etnik setempat, serta peristiwa-peristiwa yang pernah terjadi terkait hubungan antargolongan di Haurgeulis. Data tersebut telah dikumpulkan melalui teknik pengamatan terlibat, wawancara mendalam, dan studi literatur, dengan bantuan alat berupa data set, perekam suara, kamera, dan catatan lapangan. Pengumpulan data ini selanjutnya dianalisis, serta ditriangulasikan satu sama lain untuk mendukung keabsahan datanya.

Dalam penelitian ini, analisis data dilakukan sepanjang berlangsung. Analisis data diawali dengan mengumpulkan informasi di lapangan melalui pengamatan terlibat dengan mengikuti beragam aktivitas pelaku, wawancara mendalam dengan memberikan pertanyaan lanjut dari jawaban informan dan dikuatkan dengan studi literatur. Hasil wawancara kemudian ditranskrip dan hasil pengamatan ditulis dalam catatan lapangan untuk selanjutnya dianalisis lebih rinci dengan mensegmentasi kalimat-kalimat (atau paragraf) atau gambar-gambar ke dalam kategori-kategori yang berorientasi pada topik penelitian, kemudian melabeli kategori-kategori ini dengan istilah-istilah khusus berdasarkan ide-ide penelitian sebelum diinterpretasi. Selanjutnya menyajikan data ke dalam teks naratif, serta visualisasi lain. Langkah berikutnya, menginterpretasi atau memaknai setiap pengetahuan masyarakat dan peneliti ketika di lapangan, untuk selanjutnya ditulis sebagai hasil penelitian. Tahapantahapan dalam analisis data di atas merupakan bagian yang tidak saling terpisahkan, sehingga saling berhubungan antara tahapan yang satu dengan tahapan yang lainnya. Analisis dilakukan secara bertahap (kontinyu) dari awal sampai akhir penelitian.

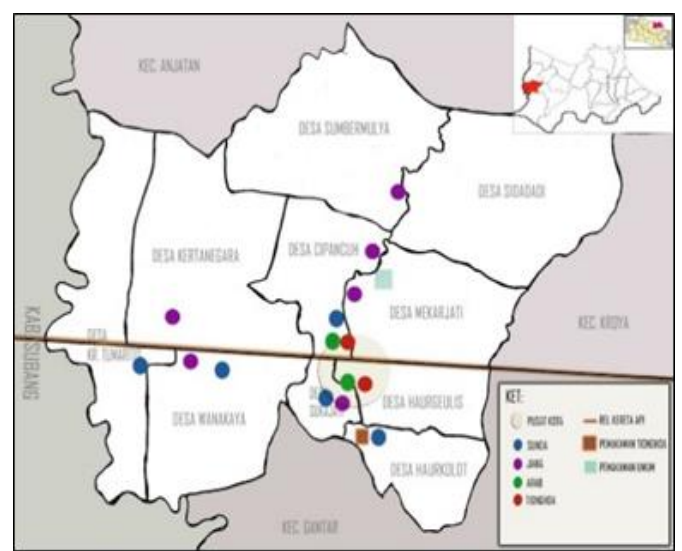

Gambar 1. Pola Pemukiman Sumber: Hasil Penelitian, 2015.

Lokasi penelitian secara umum dilakukan di pusat kota kecamatan (Desa Haurgeulis, Desa Mekarjati, Desa Sukajati, Desa Cipancuh). Ditetapkan sebagai fokus lokasi penelitian dengan pertimbangan 
desa-desa tersebut merupakan kota kecamatan yang di dalamnya terdapat beberapa golongan etnik yang tinggal atau menetap, sehingga dapat digolongkan sebagai masyarakat multikultural.

\section{HASIL DAN BAHASAN}

\section{Asal Usul Keragaman di Haurgeulis}

Haurgeulis merupakan bagian kecamatan yang terletak jauh di sebelah barat Ibukota Kabupaten Indramayu. Jaraknya mencapai sekitar 65 kilometer dari pusat Kota Indramayu. Namun, letak wilayahnya yang berada di perbatasan Subang dan Sumedang membuat Haurgeulis memiliki karakteristik masyarakat yang beragam. Kultur Jawa (Tegal) yang bertemu dengan kultur Sunda (Karawang) menjadikan Haurgeulis memiliki 2 (dua) bahasa yang umum digunakan dalam keseharian masyarakatnya, yakni bahasa Jawa dan Sunda.

Masyarakat Haurgeulis yang ditandai oleh penduduknya yang multikultural ini memiliki asal-usul masyarakat yang diawali terjadinya migrasi dari beberapa wilayah di luar kawasan Indramayu. Pada dasarnya kedatangan orang-orang ke Haurgeulis dapat dibagi ke dalam 3 (tiga) masa, yakni masa awal, masa pertengahan, dan masa sekarang. Ketiga masa ini menggambarkan asal-usul masyarakat Haurgeulis yang sesungguhnya merupakan pendatang di awal abad 20.

\section{a. Masa Awal}

(sekitar tahun 1890-1940)

Pada masa ini kebanyakan pendatang adalah orang-orang asal Karawang, Tegal, Brebes, dan Banten. Kedatangan mereka pada masa-masa awal ini tidak serta merta orang-orang datang bersamaan. Orang Karawang, Brebes, dan Tegal diketahui datang paling awal ke wilayah Haurgeulis saat itu. Menurut sebagian besar cerita masyarakat setempat, kepindahan sesepuh mereka disebabkan oleh adanya ancaman di wilayah mereka tinggal sebelumnya. Terutama disebabkan oleh adanya tekanan pajak di era penjajahan Hindia Belanda yang dianggap memberatkan, sehingga warga yang tidak mampu memilih untuk hidup berpindahpindah (nomaden), mengingat sebagian besar orang-orang dari Karawang, Tegal, dan Brebes adalah petani dan peladang.

Alasan-alasan itulah yang diketahui memberikan dorongan orang-orang di masa itu memutuskan untuk berpindahpindah dengan membuka lahan tempat mereka tinggal sementara. Kehidupan orang-orang di masa itu sangat sulit, sehingga mereka menempuh jarak dari Karawang dan Tegal ke Haurgeulis dengan berjalan kaki, bahkan sebagian dari mereka membawa serta binatang ternaknya. Perjalanan mereka menelusuri hutan-hutan untuk menghindari pasukan Hindia Belanda yang dianggap bisa saja merampas barang-barang dan ternakternak bawaannya. Sampai akhirnya banyak sekelompok orang membuka lahan-lahan yang ada untuk dijadikan lahan perkebunan dan pertanian, di mana lahan tersebut saat ini masuk ke wilayah Kecamatan Haurgeulis.

Berkat kesungguhan dan keuletan para pendatang dari berbagai wilayah tersebut dalam mengelola lahan, maka hasil perkebunan dan pertanian pun berlimpah ruah, sehingga banyak yang memutuskan untuk menetap di wilayah yang sekarang menjadi bagian selatan dari Kecamatan Haurgeulis (sekitar Desa Haurkolot) dan Kecamatan Gantar (sekitar perkampungan Wagir dan Situraja). Di sisi lain, wilayah yang saat ini menjadi pusat kota kecamatan masih dipenuhi hutan dan memang diketahui ada sekelompok pasukan Hindia Belanda saat itu di wilayah dekat Stasiun Haurgeulis.

$$
\text { Pemerintah Kolonial sendiri }
$$

memiliki kepentingan di wilayah Haurgeulis sejak tahun 1890-an. Hal ini dibuktikan dengan adanya pembangunan stasiun kereta api dan bendungan yang diberi nama Waduk Cipancuh. Pembangunan Stasiun Haurgeulis ini selain 
menjadi syarat standar jarak sebuah stasiun ke stasiun lainnya, juga digunakan sebagai akses pengiriman komoditas yang dihasilkan seperti beras dan kayu jati.

Menurut informasi warga setempat, pada masa itu (sekitar 1910-1940-an) Pemerintah Hindia Belanda membangun gudang produksi beras di bagian utara stasiun kereta yang sekarang telah menjadi perumahan di wilayah Desa Cipancuh. Pembangunan ladang-ladang sawah di sekitar Kecamatan Haurgeulis dan Gantar sudah menjadi rencana pemerintah Kolonial Hindia Belanda, sehingga mendatangkan pekerja-pekerja dari sekitar Indramayu, Cirebon, sampai Tegal. Memang menurut informasi, pekerjapekerja ini dibayar oleh Pemerintah Hindia Belanda dengan fasilitas sebidang tanah untuk dijadikan tempat tinggal, yang sekarang ditengarai berada di wilayah Desa Kertanegara dan Desa Karang Tumaritis, yang merupakan bagian dari Kecamatan Haurgeulis.

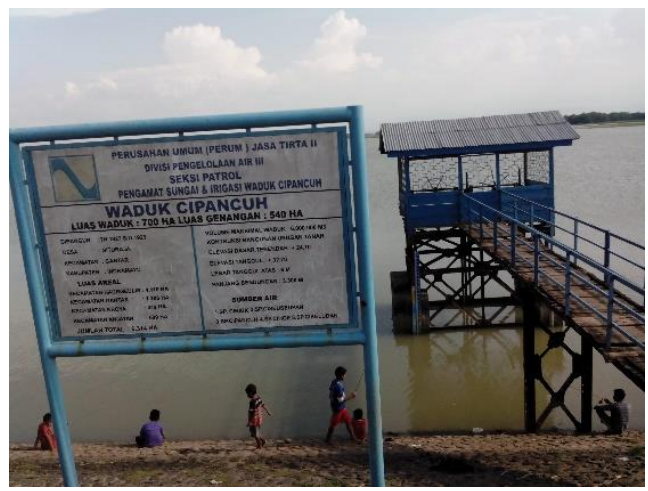

Gambar 2. Waduk Cipancuh Sumber: Dokumentasi Peneliti, 2015

Untuk mendukung produksi komoditas pertanian tersebut, Hindia Belanda membangun sebuah waduk yang sekarang masuk dalam wilayah perbatasan Kecamatan Gantar dengan Kecamatan Haurgeulis. Waduk tersebut memanfaatkan air hujan untuk kemudian ditampung dan dialirkan ke pesawahan lebih dari 6.000 hektar di wilayah Kecamatan Haurgeulis, sebagian Kecamatan Gantar, Kroya, dan Anjatan.
Pada masa-masa ini pula (sekitar tahun 1910-1920-an) banyak kelompok orang dari beberapa wilayah berdatangan, khususnya Garut, Banten, Purwakarta. Orang-orang yang berasal dari Karawang, Garut, dan Banten tergolong dalam golongan etnik Sunda, sedangkan Tegal dan Brebes tergolong dalam etnis Jawa. Kendati tergolong dalam etnik Sunda dan Jawa, karakteristik bahasa maupun dialek yang digunakan cukup beragam sesuai dari wilayahnya masing-masing. Dengan kata lain, golongan etnik Sunda dari Garut, Karawang, dan Banten memiliki dialek dan penggunaan kalimat yang berbeda, begitu pun etnik Jawa. Kedatangan Orang Banten dan Garut memang tidak sebanyak Orang Karawang, karena saat itu kedatangan mereka hanya sebagai migrasi yang didasari adanya perintah sesepuh untuk berpindah karena merasakan wilayah asalnya itu sudah tidak aman.

Lain halnya dengan Orang Banten, Garut, dan Karawang. Pendatang dari Purwakarta merupakan kelompok orang keturunan Arab yang sebagian besar sudah berbahasa Sunda. Keturunan Arab yang berasal dari Purwakarta merupakan suku Arab Bajri/Bajre, Sungkar, dan Basefan. Kedatangan keturunan Arab ke Haurgeulis pada sekitar tahun 1920-an ini masih tergolong kecil, atau hanya beberapa kelompok keluarga saja. Begitu pun perekonomian mereka di masa awal ini terbilang sulit, karena hanya mampu menjual benang kain dalam jumlah yang relatif sedikit, kecuali pada masa setelah keturunan Orang Arab banyak berdatangan ke Haurgeulis untuk berdagang terutama di sektor meubel.

\section{b. Masa Pertengahan (tahun 1940-1980)}

Masa ini masuk dalam masa pra dan pasca kemerdekaan Indonesia, sehingga campur tangan dan kekuasaan Belanda sudah berkurang di Indonesia, karena sebagian wilayahnya diduduki kolonial Jepang termasuk di sejumlah wilayah Indramayu, yang dalam masanya muncul 
gerakan perlawanan Petani Indramayu terhadap kependudukan Jepang pada tahun 1944 (lihat Nopy Yanti, 2011). Masyarakat Haurgeulis pada umumnya saat itu menyebut Tentara Jepang sebagai 'pasukan gundul'.

Sekitar tahun 1949 pernah terjadi pengeboman di sekitar stasiun Haurgeulis yang berasal dari sebuah pesawat. Menurut cerita informan, dalang pemboman itu justru adalah Pasukan Belanda yang melancarkan agresi keduanya pasca kemerdekaan Indonesia. Terjadinya pengeboman itu diduga terkait pembangunan yang telah dilakukannya di sejumlah wilayah Indramayu termasuk Haurgeulis. Dampak dari pengeboman itu sebenarnya tidak terlalu besar, karena hanya mengenai bangunan di pinggiran stasiun yang tidak ada penghuninya.

Di sisi lain, pada masa ini ditandai dengan banyaknya orang berdatangan ke Haurgeulis. Mereka berbondong-bondong datang dari sebagian kampung-kampung di Jawa Barat dan sekitarnya yang menyelamatkan diri dari ancaman perampok dan penjahat, yang saat itu disebut dengan zaman "werit". Pada zaman "werit" ini banyak kasus terkait pemberontakan-pemberontakan yang datangnya dari warga lokal sendiri, sebagaimana masyarakat Haurgeulis mengatakan pemberontakan DI (Darul Islam), PKI, dan preman-preman lokal. Seperti orang Betawi yang "hijrah" dari Cikarang ke Haurgeulis karena banyaknya pemberontakan di masa itu. Generasi pertama kedatangan orang Betawi itu berkelompok di sekitar wilayah Kecamatan Gantar, yang saat ini sudah diabadikan menjadi sebuah nama jalan yang disebut Babakan Betawi. Generasi-generasi orang Betawi berikutnya sudah bercampur baur dengan golongan etnik lain, sehingga bahasa yang digunakan pun sudah menjadi seperti masyarakat umumnya, yakni bahasa Jawa atau Sunda. Hal ini dialami juga oleh sebagian orang dari Garut yang menjadi basis pemberontakan DI (Darul Islam). Sebagian keturunan orang Garut saat itu berkelompok di Kampung Wagir, sekitar Kecamatan Gantar dan Haurgeulis.

Selain bertambah banyaknya kedatangan kelompok-kelompok keluarga dari Karawang, Tegal, dan Brebes, pada masa pertengahan ini diketahui juga banyak pendatang dari Pekalongan, Cirebon, Solo, dan Kalimantan. Kedatangan di masa pertengahan ini lebih didasarkan atas kepentingan untuk berdagang. Kedatangan sekelompok orang dari berbagai wilayah tersebut membuat karakteristik masyarakat Haurgeulis semakin beragam. Seperti orang Arab dari Pekalongan yang bermarga Arab Baraba. Berbeda dengan orang Arab dari Purwakarta, orang Arab Baraba memiliki warna kulit yang lebih gelap dibanding suku/marga Arab lainnya yang ada di Haurgeulis. Selain itu, orang Tionghoa pun sudah semakin banyak yang sebagian besar berasal dari Kalimantan Barat. Orangorang keturunan Arab dan Tionghoa ini banyak menetap di sekitar stasiun dan pasar, berbeda dengan orang-orang dari wilayah lainnya yang tinggal di pinggiran Haurgeulis.

Setelah melemahnya kekuatan Darul Islam, hal yang membuat resah masyarakat Haurgeulis saat itu adalah pemberontakan PKI yang beroperasi di pinggiran pusat Kota Kecamatan. Di masa-masa ini, pasukan Tentara Rakyat sudah memiliki kantor/markas di Haurgeulis, sehingga kelompok seperti DI dan PKI lebih terdesak ke pinggiran atau di hutan. Keresahan masyarakat, menurut kesaksian warga setempat yaitu banyak orang-orang dari PKI mencatut nama-nama warga menjadi seolah bergabung dengan PKI. Sedangkan di masa DI banyak terjadi pembakaran rumah yang dianggap pro terhadap militer Indonesia.

Pemberontakan-pemberontakan ini sebenarnya merupakan faktor yang menyebabkan pusat keramaian saat ini berada di wilayah Desa Haurgeulis. Korban-korban pemberontakan saat itu memilih untuk tinggal di sekitaran stasiun (yang masuk wilayah Desa Haurgeulis) 
karena alasan keamanan yang lebih baik. Untuk memenuhi kebutuhan ekonominya mereka menjual hasil pertanian pada warga yang sudah lebih dulu tinggal di sekitaran stasiun. Masa-masa pemberontakan (zaman werit) ini dianggap selesai pada tahun 1970-an seiring secara nasional dilakukan penangkapan-penangkapan terhadap pemberontak tersebut oleh Tentara Republik (saat ini TNI). Penumpasan anggota-anggota DI sendiri selesai dengan susah payah pada tahun 1962 di berbagai wilayah seiring diputuskannya vonis hukuman mati bagi Kartosuwiryo (Santoso, 2013:15). Adapun anggota-anggota PKI menurut pernyataan informan ditangkap dan "dibuang" di laut Pantai Utara Indramayu.

\section{c. Masa Sekarang (tahun 1980-sekarang)}

Pada masa ini pemerintahan di Haurgeulis sudah semakin baik, tata kota sudah semakin jelas dan memiliki organisasi atau kelembagaan yang berfungsi dengan baik. Begitu pun peran masyarakat dalam membangun perekonomian berjalan dengan pesat. Perekonomian masyarakat Haurgeulis pada masa awal 1980-an terangkat oleh usaha sarang walet. Haurgeulis terkenal dengan kualitas sarang walet yang banyak diminati pasar, sehingga bermunculan pengusaha lokal dan investor dari luar kota. Begitu banyaknya burung walet yang berdatangan, sehingga para pengusaha dadakan ini membuat gedung-gedung tinggi untuk dijadikan tempat atau kandang untuk burung walet.

Maraknya perdagangan sarang walet, menarik minat sebagian orang untuk berdatangan ke Haurgeulis, dan menetap hingga sekarang. Walaupun bisnis sarang walet semakin menurun, warga pendatang ini sebagian besar tetap tinggal di Haurgeulis karena sudah memiliki bisnis sampingan yang bisa menghidupi kesehariannya.

Semakin ramainya perdagangan di Kota Kecamatan Haurgeulis, semakin banyak pula pendatang yang berdagang dari sektor usaha lain, mengingat nama Haurgeulis semakin terdengar setelah maraknya pemberitaan tentang bisnis walet. Seperti kedatangan dari wilayah lainnya berdasarkan etnik adalah Minangkabau, Batak, dan Tionghoa dari Kalimantan Barat. Kedatangan mereka bukan secara khusus untuk berbisnis walet, melainkan memenuhi kebutuhan lainnya karena mereka menyadari semakin besar perputaran uang di suatu wilayah, maka semakin besar kebutuhan suatu masyarakat sekalipun wilayah tersebut adalah kota kecil seperti Haurgeulis.

Mobilitas yang cukup tinggi ditunjukkan oleh kedatangan orang Arab dan Tionghoa di Haurgeulis pada masa ini. Sebagai golongan etnik yang dalam sejarah kedatangannya cukup panjang di Indonesia, orang Tionghoa dan Arab di Haurgeulis sebenarnya sudah berinteraksi dengan masyarakat lokal. Hal ini didasarkan pada asal muasal mereka yang sebelum bermigrasi ke Haurgeulis sudah tinggal di lingkungan yang ciri-ciri sosiokulturalnya lokal seperti Jawa dan Sunda (Arab dan Tionghoa), serta Melayu (Tionghoa Kalimantan), sehingga kebiasaan-kebiasaan mereka sudah menyerupai masyarakat Jawa, Sunda dan Melayu pada umumnya.

Mobilitas yang tinggi juga ditunjukkan oleh kedatangan orang Minangkabau di Haurgeulis yang sebagian dari mereka sudah menikah dengan orang keturunan Jawa dan Sunda, sehingga memilih untuk menetap di Haurgeulis dan merasa dirinya sudah menjadi orang Haurgeulis. Sebagian besar orang Minangkabau sudah memiliki spesialisasi perdagangan/jasa di sektor tertentu, sehingga usahanya dengan cepat dapat berkembang di kota kecil ini. Selain itu, spirit orang Minangkabau untuk merantau pada dasarnya cukup tinggi. Ihwal spirit tersebut, orang Minangkabau di Haurgeulis cenderung merujuk pada struktur etnik mereka yang sejatinya harus merantau. Ketika mereka sudah ada di tanah 
perantauan maka biasanya mereka membaur dengan warga 'lokal'. Hal ini pada dasarnya diakui untuk memudahkan usaha perdagangan/jasa mereka yang disesuaikan dengan kebutuhan masyarakat setempat.

\section{Tidak Adanya Kebudayaan Dominan}

Masyarakat multikultural terwujud di tempat-tempat yang menjadi pusat pertemuan antargolongan sosial-budaya dan salah satu tempat demikian yang terpenting biasanya adalah kawasan perkotaan (Parekh, 2008). Kehidupan di kota kecil ini diwarnai berbagai faktor sosial-ekonomi-politik yang melatari terjadinya migrasi ke Haurgeulis sebagaimana dijelaskan di awal.

Masyarakat di Haurgeulis merupakan pendatang dari beberapa wilayah yakni Tegal (orang Jawa dan Arab Baraba), Karawang (orang Sunda), Purwakarta (Arab Bajri), serta Semarang dan Kalimantan (Tionghoa) yang datang pada kisaran akhir abad ke-19 dan awal abad-20. Pengalaman golongan-golongan etnik yang telah hidup bersama di Haurgeulis sejak masa awal kedatangannya semakin membentuk pandangan baru pada individu yang diwujudkan melalui penerimaan-penerimaan terhadap liyan.

Penerimaan ini merupakan bentuk kesediaan individu dalam berhubungan dengan orang lain yang berbeda sukubangsa dalam berbagai bidang kehidupan. Salah satu penerimaan yang paling tinggi adalah adanya perkawinan antaretnik (lihat Seo, 2013). Melalui perkawinan, hubungan kekerabatan di antara golongan etnik di Haurgeulis semakin luas, dan hal ini pula yang menyebabkan pola pemukiman berdasarkan golongan etnik di Haurgeulis semakin tersebar, khususnya di wilayah pusat kecamatan.

Pola pemukiman yang semakin menyebar, membuat warga dari beragam golongan etnik ini berinteraksi lebih intens. Oleh karena itu pertemuan antargolongan etnik ini melahirkan kosakata atau dialek yang berbeda seiring antargolongan etnik ini hidup bersama dalam waktu yang cukup lama.

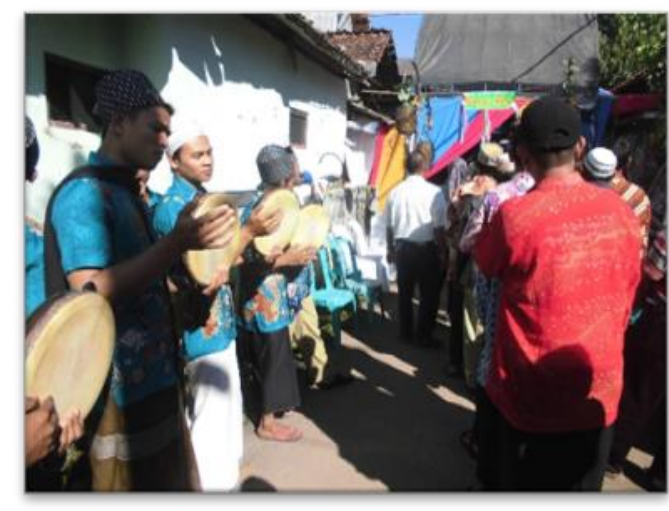

Gambar 3. Iring-iringan Perkawinan Sumber: Dokumentasi Peneliti,2015

Sebagai masyarakat yang merupakan keturunan pendatang dari beberapa wilayah, warga masyarakat Haurgeulis sulit mengidentifikasi diri sebagai penduduk asli atau pendatang berdasarkan sukubangsa tertentu (kecuali orang Minangkabau dan Batak yang baru datang ke Haurgeulis pada tahun 1990-an) mengingat gelombang pendatang orang Sunda, Jawa, Arab, dan Tionghoa masuk hampir dalam masa yang bersamaan di awal abad ke-20. Itu pula yang menyebabkan warga setempat mengakui bahwa mereka adalah keturunan pendatang.

Beberapa studi tentang etnisitas pada masyarakat multikultural menjelaskan bahwa hubungan antaretnik dipengaruhi oleh dominasi kebudayaan. Dominasi kebudayaan pada masyarakat multikultural ini akan terkait dengan kedudukan suatu sukubangsa dengan sukubangsa lainnya, yang utamanya terjadi pengkategorian sebagai penduduk "asli" (pribumi) dengan pendatang.

Sebagaimana bertolak dari hipotesis kebudayaan dominan (Bruner, 2000; lihat juga Suparlan, 2005) bahwa syarat atas adanya kebudayaan dominan di suatu wilayah multikultural adalah: (1) komponen demografi sosial, yang dilihat berdasarkan adanya penduduk "asli" mayoritas dari satu golongan etnik; (2) 
kebudayaan daerah, di mana penduduk "asli" tersebut memiliki kebudayaan yang mapan; dan (3) letak kekuasaan yang memengaruhi pola-pola hubungan.

Bila ketiga komponen itu didominasi oleh satu golongan etnik, maka dalam wilayah multikultural dianggap memiliki kebudayaan dominan. Dengan adanya kebudayaan dominan di suatu wilayah, maka orang-orang dengan status pendatang akan berorientasi pada kebudayaan dominan, mengikuti kebiasaan tuan rumah yang kebudayaannya dominan. Sementara bila tidak ada kebudayaan dominan, maka pendatang akan mengikuti keragaman etnik yang ada.

Mengacu pada hipotesis di atas, maka Haurgeulis merupakan kota kecil yang memiliki golongan etnik mayoritas di antara penduduknya. Namun penduduk dari golongan mayoritas tersebut tidak menganggap dirinya sebagai penduduk "asli". Anggapan tersebut muncul disebabkan Haurgeulis merupakan tanah yang awal mulanya dihuni oleh penduduk dari beragam latar belakang budaya.

Tidak adanya masyarakat "pribumi" dan kebudayaan dominan di Haurgeulis, menyiratkan bahwa masyarakat Kota Kecamatan Haurgeulis pada dasarnya dibangun oleh pendatang (settler society). Menurut Razack (2002, dirujuk Cormack, 2010), etnisitas pada masyarakat pendatang tidak memberlakukan hak-hak yang sifatnya memarginalisasikan golongan minoritas, kebijakan eksploitasi, dan pengucilan non-dominan lainnya di antara kehidupan masyarakat.

Hal ini mengindikasikan bahwa konsep dari Bruner (2000) tentang ekspresi kesukubangsaan tidak cukup memberikan penjelasan secara utuh untuk gejala seperti di Kota Kecamatan Haurgeulis. Realitas multikultural yang terjadi di Haurgeulis memberikan pandangan lain bahwa telah terjadi negosiasi identitas etnik, karena tidak ada rujukan kebudayaan dominan bagi golongan etnik yang ada di Haurgeulis. Negosiasi identitas tersebut bersifat saling tarik-menarik kebudayaan sukubangsa. Namun, karena orang Arab dan Tionghoa di Haurgeulis sebelum kedatangannya ke Haurgeulis sudah berasimilasi dengan masyarakat lokal di Karawang (Arab Bajri) dan Tegal (Arab Baraba), maka identitas Jawa dan Sunda lebih kuat. Itu pula mengapa bahasa dominan di Haurgeulis adalah Jawa dan Sunda. Etnisitas tersebut dikonstruksi oleh para pendatang di Haurgeulis menjadi sebuah masyarakat multikultural yang dalam perkembangannya memiliki perbedaan karakteristik budaya dengan tempat sebelumnya.

\section{Ruang Etnisitas dalam Hubungan Multikultural}

Etnisitas dalam perkembangannya dipengaruhi oleh unsur-unsur lain yang membentuk pandangan dan tindakan individu/kelompok. Di antaranya pribumipendatang dan agama. Kedua unsur tersebut tak jarang menjadi acuan meluasnya konflik antargolongan sosial. Perihal itu tidak selalu bisa dihindari terutama pada masyarakat multikultural di kota kecil.

Namun, ada beberapa pengecualian di Haurgeulis terkait kedua unsur di atas. Fenomena semakin bertambahnya jumlah pendatang baik atas kemauan sendiri maupun mengikuti kawan atau kerabat yang sudah terlebih dahulu datang, justru dianggap warga memberikan kontribusi besar terhadap perekonomian di Haurgeulis, alih-alih sebagai ancaman.

Begitupun bagi pendatang, tidak pernah merasakan perlakuan diskriminatif sekalipun termasuk golongan etnik minoritas. Haurgeulis merupakan kota kecil yang sedang berkembang untuk dijadikan tempat hidup atau pun hanya tinggal sementara. Peluang untuk membuka usaha di Haurgeulis masih terbuka lebar dibandingkan di tempat mereka tinggal sebelumnya yang relatif padat, dengan tingkat persaingan lebih tinggi. Atas pertimbangan itu Kota Kecamatan Haurgeulis ini banyak diminati oleh pendatang di masa sekarang (selain sejarah mencatat kedatangan awal orang 
Haurgeulis yang merupakan kelompok migran) yang berasal dari luar wilayah Indramayu untuk sekadar berdagang tanpa menetap atau secara permanen menetap. Pandangan warga tersebut berpengaruh terhadap keberlangsungan hubungan antaretnik, yang setidaknya dapat meminimalisasi konflik.

Selain masalah kategorisasi pribumipendatang, masalah kategori agama juga dapat menimbulkan konflik. Sejumlah masyarakat menempatkan agama yang dianutnya sebagai inti atau puncak kebudayaan, yang biasanya menjadi pedoman bagi kehidupan masyarakat sukubangsa yang bersangkutan (Suparlan, 2005:71). Agama dapat menambah 'ketebalan' batas anggota golongan etnik dengan anggota dari golongan etnik lainnya, terutama yang memiliki keyakinan agama berbeda. Besar kecilnya pengaruh agama, atau kuat lemahnya posisi agama dalam kehidupan multikultural bergantung pada hasil interpretasi atas agama tersebut oleh anggota golongan etnik.

$$
\text { Merujuk pada keragaman }
$$
sukubangsa dan agama di Haurgeulis, maka golongan etnik Arab, Minangkabau, Sunda, dan Jawa merupakan golongan etnik yang mayoritas anggotanya beragama Islam, sedangkan Tionghoa memiliki label agama Kristen atau agama Budha/Konghucu pada anggotanya. Secara nasional, kenyataan tersebut telah menimbulkan banyak gesekan antara Tionghoa dengan golongan etnik lainnya (Hoon, 2010).

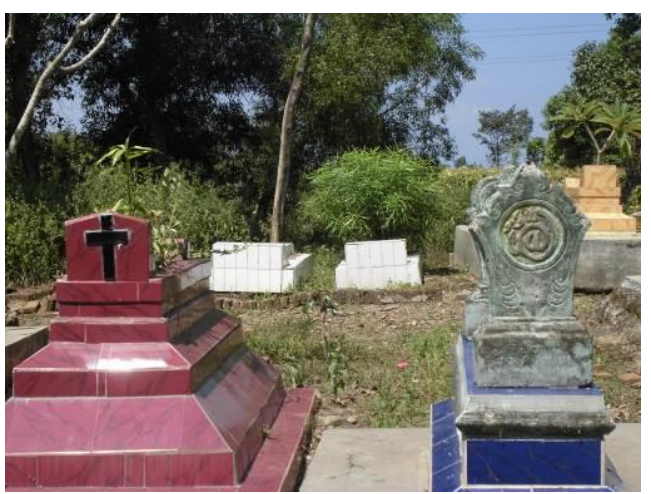

Gambar 4. Pemakaman Antaragama Sumber: Dokumentasi Peneliti, 2015.
Kendati orang Arab merupakan golongan yang berasal dari bangsa Timur Asing (seperti Tionghoa), namun mereka (keturunan Arab) berada pada posisi yang lebih tinggi dalam berhubungan dengan golongan etnik lainnya di Haurgeulis karena adanya kesamaan agama, yakni Islam. Sebaliknya Tionghoa berada pada posisi berbeda antara Pri dan Non-Pri karena dilabeli sebagai agama yang penganutnya lebih sedikit, yakni Kristen. Menurut De Jonge dan Kaptein (2002:185), bagian budaya Arab secara tradisional di Asia Tenggara termasuk di wilayah Indonesia sebagai negara mayoritas Muslim menjadi model peranan yang diikuti kebanyakan Muslim lokal, seperti pakaian orang Arab dan pemberian nama Arab. Hal ini tidak mengejutkan bahwa Arab dimanifestasikan ke dalam ranah agama, yakni Islam.

Haurgeulis sebenarnya memiliki catatan khusus terkait konflik, yaitu adanya dua peristiwa yang berkaitan dengan sentimen agama. Peristiwa pertama pembakaran gereja yang didalangi segelintir "preman" yang berseteru dengan orang Tionghoa di Haurgeulis pada tahun 2008. Peristiwa lainnya pada tahun 2005 , ketika Haurgeulis menjadi sorotan media terkait perseteruan antara MUI setempat dengan seorang Tionghoa dan dua orang keturunan Jawa/Sunda yang dituduh sebagai misionaris Kristen yang melakukan kristenisasi terhadap anak-anak beragama Islam melalui sebuah program anak bernama Minggu Ceria, dan kristenisasi terhadap pasien pelayanan kesehatan gratis (Crouch, 2006; lihat juga Mubarok, 2014).

Namun, peristiwa-peristiwa yang melibatkan sentimen sukubangsa dan agama tersebut dapat diredam dengan cepat oleh warga dari golongan etnik lainnya, sehingga konflik tidak meluas ke tingkat komunal. Bahkan sebagian warga lain yang notabene beragama Islam dan non-Tionghoa membantu melindungi warga Tionghoa tersebut dari ancaman konflik. Warga mengasosiasikan peristiwa- 
peristiwa itu bukan antara warga beragama Islam dengan warga Kristen, melainkan hanya sekelompok orang atau organisasi dengan warga agama lain yang kebetulan seorang Tionghoa atau Kristen.

Ungkapan-ungkapan informan terkait hubungan antara etnik dan agama menyiratkan dua pandangan. Pertama, bahwa agama dapat menumbuhkan rasa kebersamaan atau membatasi antara satu golongan etnik dengan etnik lainnya. Pandangan ini sebenarnya diungkapkan oleh informan-informan yang sebagian besar beragama Islam. Pandangan ini juga umumnya dilembagakan oleh masyarakat dalam masalah perkawinan, seperti "siapa dapat menikah dengan siapa". Pernyataan tersebut merupakan hal yang umum dalam kehidupan masyarakat Haurgeulis. Dengan kata lain, kriteria agama hanya berlaku dalam pengambilan keputusan perkawinan, dalam hubungan lainnya tidak begitu dipermasalahkan.

Kedua, pandangan bahwa agama tidak memengaruhi hubungan antaretnik. Hal ini diilustrasikan oleh informan melalui penafsirannya bahwa sesama Islam atau sesama Kristen dapat terjadi konflik. Artinya, konflik-konflik yang terjadi dalam masyarakat multikultural bukan karena dipersatukan atau dibedakan oleh agama, melainkan relativitas dari bagaimana cara individu memandang yang 'liyan'. Dengan demikian, bentuk-bentuk kerjasama antargolongan etnik di Haurgeulis lebih besar daripada konflik yang terjadi. Konflik itu pun hanya melibatkan kelompok dengan individu, alih-alih meluas menjadi konflik antargolongan.

\section{Distribusi Pekerjaan: Faktor Mutualisme Antargolongan Etnik}

Tidak adanya kebudayaan dominan di Haurgeulis, memberikan keleluasaan warga dari beragam golongan etnik tersebut untuk berkompetisi dalam menentukan pekerjaan. Dominasidominasi di berbagai sektor pekerjaan lebih terbuka bagi setiap golongan etnik yang ada, sekalipun warga dari golongan etnik minoritas. Namun, hal yang perlu ditandai terkait preferensi pekerjaan golongan etnik di Haurgeulis adalah kedatangan mereka (generasi awal) yang sudah memiliki keahlian-keahlian khusus.

Warga keturunan Sunda dan Jawa, sejak awal kedatangannya berprofesi sebagai petani. Tidak heran mengapa jenis pekerjaan penduduk Haurgeulis sampai sekarang yang paling banyak adalah di bidang pertanian. Itu karena orang Jawa dan Sunda di Haurgeulis juga adalah penduduk yang hampir berimbang dan lebih besar dibandingkan golongan etnik lainnya. Demikian juga bagi orang Arab dan Tionghoa, yang sejak masa awal kedatangannya berprofesi sebagai pedagang. Mereka mengisi beragam jenis perdagangan di pusat Haurgeulis.

Distribusi pekerjaan berdasarkan sukubangsa ini sangat penting, karena sumber masalah yang sering menjadi konflik adalah persoalan mendapatkan peluang yang sama dalam pekerjaan. Klinken (2007) mengingatkan bahwa konflik-konflik yang melibatkan etnisitas salah satunya adalah akibat adanya ketimpangan distribusi pekerjaan antara kelompok etnik satu dengan kelompok etnik lainnya, terutama antara tuan rumah dan pendatang. Jika merujuk analisis Klinken tersebut, hal pertama yang tidak berlaku di Haurgeulis adalah tidak adanya pembedaan antara tuan rumah dan pendatang berdasarkan sukubangsa; kedua, bidang-bidang pekerjaan yang secara umum menjadi preferensi bagi masingmasing golongan etnik di Haurgeulis sudah jelas, sehingga distribusi pekerjaannya tidak menimbulkan ketimpangan. Dengan kata lain, kecenderungan tersebut mempersempit ruang konflik antaretnik di Haurgeulis, karena masing-masing golongan etnik memiliki posisi di sektor pekerjaan tertentu yang satu sama lain saling berperan.

Prinsip saling membutuhkan tanpa melihat latar belakang budaya, menjadi acuan terjadinya hubungan mutualis yang 
melahirkan integrasi antaretnik di Haurgeulis. Integrasi ini dapat dilihat dalam aktivitas perdagangan di pasar maupun di tempat perdagangan lainnya.

Mutualisme hubungan antaretnik ini memberikan gambaran bahwa tidak adanya ketimpangan dalam distribusi pekerjaan dapat berdampak positif terhadap hubungan antarindividu maupun antarkelompok, sehingga konflik dapat dikurangi atau diredam.

\section{PENUTUP}

Masyarakat kota Kecamatan Haurgeulis merupakan tipikal masyarakat multikultural di kota kecil yang dibentuk oleh para pendatang keturunan Jawa, Sunda, Arab, dan Tionghoa di awal abad ke-20. Selain itu, kedatangan Hindia Belanda di Kota Kecamatan Haurgeulis merupakan faktor lain terbentuknya masyarakat multikultural.

Sebagai masyarakat yang dibangun oleh kelompok pendatang, kehidupan multikultural di Haurgeulis dicirikan oleh tidak adanya kebudayaan dominan. Hal ini berdampak pada tidak adanya klaim sebagai tuan rumah atau golongan etnik "asli", sehingga kesadaran berpandangan positif dan bersikap menghargai dari anggota-anggota golongan etnik terhadap golongan etnik lainnya menjadi lebih besar.

Sikap menghargai tersebut, sebenarnya dipengaruhi juga oleh adanya keadilan dalam mengisi jenis-jenis pekerjaan di Haurgeulis. Setiap golongan etnik di Haurgeulis memiliki spesialisasi atau keahlian dalam pekerjaannya. Orang Jawa dan Sunda mayoritas bekerja di bidang pertanian dan perkantoran, serta orang Arab, Tionghoa, dan Minangkabau yang mayoritas bekerja di bidang perdagangan. Hal ini berdampak positif, di mana masing-masing golongan etnik memiliki peranan dalam kehidupan sosial, ekonomi, maupun politik.

Pengalaman historis hidup bersama yang dieksternalisasikan beragam sukubangsa yang menetap di Haurgeulis semakin membangun pengetahuanpengetahuan baru tentang kebudayaan liyannya, sehingga dalam interaksinya seseorang menjadi lebih paham tentang liyannya. Dengan demikian, membangun nilai multikulturalisme pada masyarakat Haurgeulis tidak terlepas dari adanya pengalaman hidup masing-masing yang diinteralisasikan oleh individu dalam menjalani kehidupan sosial-budayanya dan keseimbangan dalam pengelolaan sumberdaya, serta adanya peranan masingmasing golongan etnik dalam distribusi pekerjaan. Batas-batas dalam hubungan sosial dengan liyan semakin kecil, ketika sumber-sumber konflik tidak begitu melekat pada masyarakatnya. Maka, sikap berprasangka, diskriminatif, atau lebih jauh konflik antaretnik pada masyarakat multikultural di Haurgeulis dapat diredam dengan cepat dan tidak meluas menjadi konflik komunal.

Oleh karena itu, harmonisnya hubungan antaretnik di Kecamatan Haurgeulis merupakan tanggung jawab seluruh warga masyarakat Kecamatan Haurgeulis. Hubungan antarwarga yang sejauh ini telah berlangsung dengan baik merupakan keadaan positif yang perlu dipertahankan oleh warga, organisasi masyarakat, dan pemerintah di Haurgeulis. Namun, bukan tidak mungkin keadaan positif tersebut dapat berubah sewaktuwaktu ke arah hubungan antaretnik yang negatif, yakni konflik. Oleh karena itu, ditemukan sejumlah implikasi yang sekiranya dapat menjadi rujukan bagi pihak-pihak yang bersangkutan.

Keadaan positif dapat tercapai jika, Pemerintah membentuk forum diskusi rutin bagi tokoh-tokoh agama atau sukubangsa setempat, dan sedianya dapat bekerjasama dalam mendokumentasikan keragaman budaya di Haurgeulis, agar tradisi multikulturalis pada warga masyarakat tetap terwariskan; organisasi masyarakat dapat menjadi media yang memfasilitasi warga dari beragam sukubangsa dalam menjaga kerukunan antarwarga di Haurgeulis; warga (orang 
tua) dari beragam golongan etnik dapat menyekolahkan anaknya di sekolah umum, karena kerukunan antarwarga multikultural di Haurgeulis salah satunya terbentuk dari sejak masa sekolah yang siswanya beragam latar belakang sukubangsa.

Lalu keadaan negatif dapat muncul

jika, organisasi-organisasi agama di Kecamatan Haurgeulis bersikeras membawa nama kelompok etnik dan agamanya dalam setiap masalah sosialindividu (seperti dapat dilihat dalam riwayat konflik Haurgeulis); pemerintah setempat bersikap tidak adil dalam memberikan keleluasaan upacara keagamaan khususnya pada golongan minoritas; terjadi ketimpangan antara lahan pertanian dan lahan perdagangan, karena saat ini sedang banyak dibangun ruko modern di bekas lahan pertanian. Maka, pemerintah bertanggung jawab dalam mengelola masalah penggunaan lahan ini.

\section{UCAPAN TERIMA KASIH}

Tulisan ini tidak lepas dari kebaikan dan kesabaran berbagai pihak yang telah banyak membantu dalam mengarahkan tulisan menjadi lebih baik. Oleh karena itu, selayaknya penulis ucapkan terima kasih kepada Bapak Prof. Haryo S. Martodirdjo, Drs Budhi Gunawan, M.A., Ph.D., Dr. Budi Rajab, M.Si., Ibu Dr. Dra. Selly Riawanti, M.A., dan Dr. Dra. Budiawati Supangkat. M.A., selaku dosen yang begitu sabar dan teliti mengantarkan penulis menuju gerbang Antropologi. Serta kepada Bapak Drs. Asep Kusdianti, M.Si., selaku Camat Haurgeulis, yang telah memberikan informasi awal tentang Haurgeulis. Bapak Tarmo, selaku Kepala Statistik Kecamatan Haurgeulis, yang bersedia meluangkan waktunya untuk memberikan data-data relevan dan kepada Kang Dede, Uda Edi, Mas Rudi, Pak Agus, Ibu Sri, Ibu Hj. Sophiah, serta segenap warga Kecamatan Haurgeulis yang memiliki keterlibatan langsung dengan peneliti selama di lapangan. Akhir kata, peneliti haturkan terima kasih, dan semoga kita tetap menjadi manusia yang bermanfaat dengan caranya masingmasing.

\section{DAFTAR SUMBER}

\section{Jurnal dan Skripsi}

Crouch, Melissa. 2006. "The Proselytisation Case: Law, the Rise of Islamic Conservatism and Religious Discrimination in West Java". Australian Journal of Asian Law, Vol. 8 No.3.

Hadi, Syofyan. 2013. "Negara Islam Indonesia: Konsepsi Shajarah Tayyibah dalam Konstruk Negara Islam". Journal of Qur'an and Hadith Studies, Vol. 2, No. 1 .

Humardhani, Fiali. 2015. Tradisi Luruh Duit: Studi Kasus tentang Ayla (Anak yang di Lacurkan) di Kecamatan Haurgeulis Kabupaten Indramayu. Skripsi. Purwokerto: Universitas Jendral Soedirman.

Mubarok, Husni. 2014. "Babak Baru Ketegangan Islam dan Kristen di Indonesia". Studia Islamika, Vol. 21 No. 3 .

Nopy Yanti, Eny. 2011. Pendudukan Jepang di Jawa Barat Tahun 1942-1945. Skripsi. Jember: Universitas Jember.

Seo, Myengkyo. 2013. "Falling in Love and Changing God: Inter-Religious Marriage and Religious Conversion in Java, Indonesia". Routledge Vol. 41, No. 119.

\section{Buku}

Berger, L. Peter dan Luckmann, Thomas. 2013. Tafsir Sosial Atas Kenyataan: Risalah tentang Sosiologi Pengetahuan (Cetakan kesepuluh). Terjemahan Hasan Basari. Jakarta: LP3ES.

Bruner, Edward. 2000.

"Kerabat dan Bukan Kerabat". Dalam T.O. Ihromi (Penyunting). Pokok-pokok Antropologi Budaya, hlm 159-179. Jakarta: Yayasan Obor Indonesia.

Cormack D. 2010.

The Practice and Politics of Counting: Ethnicity Data in Official Statistics in 
Aotearoa/New Zealand. Wellington: Te Rōpū Rangahau Hauora a Eru Pōmare.

Creswell, W. John. 2013.

Research Design: Pendekatan Kualitatif, Kuantitatif, dan Mixed (edisi ketiga). Terjemahan Achmad Fawaid. Yogyakarta: Pustaka Pelajar.

De Jonge, Huub dan Kaptein, Nico. 2002. Transcending Borders: Arabs, Politics, Trade and Islam in Southeast Asia. Leiden: KITLX Press.

Hoon, Chang Yau. 2012.

Identitas Tionghoa Pasca Suharto: Budaya, Politik dan Media. Terjemahan Budiawan. Jakarta: LP3ES.

Klinken, Van. G. 2007.

Perang Kota Kecil: Kekerasan Komunal dan Demokratisasi di Indonesia. Terjemahan Bernard Hidayat. Jakarta: Yayasan Obor.

Kymlicka, Will. 2002. Kewargaan Multikultural. Terjemahan Edlina Hafmini Eddin. Jakarta: LP3ES.

Lewellen, Ted. C. 2003.

Political Anthropology : An Introduction (edisi etiga). London: Praeger Publisher.

Parekh, Bikhu. 2008.

Rethinking Multiculturalism:

Keberagaman Budaya dan Teori.

Terjemahan Bambang Kukuh Adi.

Yogyakarta: Kanisius.

Salim, Agus. 2006.

Stratifikasi Etnik: Kajian Mikro Sosiologi Interaksi Etnis Jawa dan Cina. Yogyakarta: Tiara Wacana.

Samovar, L.A, Richard E.P, \& Edwin R.M. 2014.

Komunikasi Lintas Budaya (edisi ketujuh). Terjemahan Indri Margaretha. Jakarta: Salemba Humanika.

Santoso, Budi M.H. 2013.

Darul Islam: Pemberontakan di Jawa Barat. Bandung: Pustaka Jaya.

Suparlan, Parsudi. 2005.

Sukubangsa dan Hubungan AntarSukubangsa (Edisi kedua). Jakarta: YPKIK Press. 
